Proceeding ICOGISS 2019

Page 81-90. ISBN: 978-602-6 988-75-1

Web Jurnal Online: jurnal.unmuhjember.ac.id

By: Putri Robiatul Adawiyah

Street Food Market Pasar Kampoeng Kopat Boyolangu Village Giri District

Banyuwangi Regency

\title{
STREET FOOD MARKET PASAR KAMPOENG KOPAT BOYOLANGU VILLAGE GIRI DISTRICT BANYUWANGI REGENCY
}

\author{
By: Putri Robiatul Adawiyah \\ Ilmu Pemerintahan FISIP Universitas Muhammadiyah Jember \\ Email: putri.ra@unmuhjember.ac.id
}

\begin{abstract}
This study aims to find out how the process of community empowerment through the use of symbols of values and traditions of the people in Boyolangu Village, Giri District, Banyuwangi Regency. The symbol used by the community is the Kampoeng Kopat Street Food Market. This research was conducted using qualitative descriptive methods. The results showed that the Boyolangu Village Community had a variety of potentials including potential socio-cultural values such as the tradition of Puter Kayun and Barong Ider Bumi Torch so that this potential was used to create a new tradition, Street Food Market every Saturday night. Besides the program support from the village in the form of business capital assistance development for women members of the Boyolangu women's cooperative, it can be used to support women for the business capital used when selling various dishes, especially ketupat at the Kampoeng Kopat Boyolangu event.
\end{abstract}

Keywords: Street Food Market, Empowerment 
Proceeding ICOGISS 2019

Page 81-90. ISBN: 978-602-6 988-75-1

Web Jurnal Online: jurnal.unmuhjember.ac.id

By: Putri Robiatul Adawiyah

Street Food Market Pasar Kampoeng Kopat Boyolangu Village Giri District

Banyuwangi Regency

\section{Introduction}

This research is titled Street Food Market, Kampoeng Kopat Market, Boyolangu Village, Giri District, Banyuwangi Regency. This study aims to find out how the process of Community Empowerment Through Utilization of the Symbols of Values and Traditions of the Community in Street Food Market, Kampoeng Kopat Market, Boyolangu Village, Giri District, Banyuwangi Regency. The importance of solutions to the problem of exploiting local culture is needed in order to support local food security and Islamic food. Departing from the local potential owned by a community leader in Boyolangu Village, how the community manages its potential by identifying the potential and values that already exist in the community. The process of accepting the transition from values that become a symbol of society to be used as social capital for community empowerment is not an easy matter. It is possible that the community will immediately accept and approve the process or even reject the process and the change is caused by worrying about changing the values and symbols that already exist in the community. But in Boyolangu Village, it was seen in an activity called Kampoeng Kopat Street Food Market, the community was very enthusiastic in participating and supporting the process of change in utilizing the values and symbols that already existed in the community, in order to increase community potential in Giri Sub-District Boyolangu Village Banyuwangi Regency. Based on this background, researchers were interested in knowing the process of how the people of Boyolangu Village Village used the values and traditions of Kampoeng Kopat Street Food Market to empower the people of Boyolangu Village, Giri District, Banyuwangi Regency.

\section{Formulation of the problem}

In this study the formulation of the problem given is how the process of utilizing symbols of the values and traditions of the people in the Street Food Market in Kampoeng Kopat Street Food Market, Boyolangu Village, Giri District, Banyuwangi, Limits in this study are as follows: a. Identify what potentials the community has $b$. What values and symbols are used for community empowerment. c. The mechanism and method used by the community in integrating the concept of Street Food Market in Kampoeng Kopat Boyolangu Giri.

\section{Research Objectives and Outcomes}

The purpose of the study was to find out how the process of Community Empowerment through the use of symbols of community values and traditions at the Street Food Market in Kampoeng Kopat Market, Boyolangu Village, Giri District, Banyuwangi Regency. The output target of this study is as follows. 1. Report on research activities on community empowerment processes through the use of symbols of community values and traditions in the street food market in Kampoeng Kopat Market, Boyolangu Village, Giri District, Banyuwangi Regency. 2. Scientific articles published in accredited or international national journals. 
Proceeding ICOGISS 2019

Page 81-90. ISBN: 978-602-6 988-75-1

Web Jurnal Online: jurnal.unmuhjember.ac.id

By: Putri Robiatul Adawiyah

Street Food Market Pasar Kampoeng Kopat Boyolangu Village Giri District

Banyuwangi Regency

\section{LITERATURE REVIEW}

\subsection{Community Empowerment Through the Use of Symbols of Community Values and Traditions}

\subsubsection{Definition of community empowerment}

Robinson (1994) explains that empowerment is a personal and social process; a liberation of personal ability, competence, creativity and freedom of action. Whereas Ife (1995) suggests that empowerment refers to the word "empowerment," which means giving power, giving "power" (power), power, to those who are powerless. Payne (1997) explains that empowerment essentially aims to help clients gain the power, strength and ability to make decisions and actions to be taken and related to the client, including reducing personal and social constraints in taking action. People who have achieved collective goals are empowered through their independence, even as a "necessity" to be more empowered through their own efforts and accumulation of knowledge, skills and other resources in order to achieve goals without depending on help from external relations. Slamet (2003) explains in more detail that what is meant by empowered society is people who know, understand, understand motivated, have the opportunity, take advantage of opportunities, energize, are able to work together, know alternatives, be able to make decisions, take risks, are able to find and capture information and able to act in accordance with the situation. The empowerment process that gives birth to communities that have the expected characteristics must be carried out continuously by optimizing community participation responsibly.

According to Suharto (2005: 60), community empowerment is also interpreted as a process and purpose, as a process, empowerment is a series of activities to strengthen weak groups in society, including individuals who experience problems of poverty. As an objective, empowerment refers to the conditions to be achieved by a social change, namely a community that is empowered, has the power or knowledge and ability to fulfill their needs both physically, economically and socially such as self-confidence, express aspirations, have a livelihood, participate in social activities, and independent in carrying out life's tasks. According to Fahrudin (2012: 96-97), community empowerment is an effort to enable and empower the community carried out with the following efforts: enabling, empowering, protecting, According to Mardikanto (2014: 202), there are six goals of community empowerment, namely: institutional improvement (better institution), better business improvement, income improvement (better income), better environment (better environment), better living, better community.

The Principles of Community Empowerment are often used for the success of empowerment programs, namely the principle of equality, participation, self-reliance or independence, and sustainability (Najiati et al., 2005: 54). The explanation of the principles of community empowerment are: the principle of equality, participation, selfreliance or independence, and sustainability. Based on a number of references, the conclusion is that community empowerment is an effort to empower (empower) or strengthen the community. Community empowerment is also defined as the ability of individuals in the community to build the empowerment of the community concerned so that later it aims to find solutions in community development. The community 
Proceeding ICOGISS 2019

Page 81-90. ISBN: 978-602-6 988-75-1

Web Jurnal Online: jurnal.unmuhjember.ac.id

By: Putri Robiatul Adawiyah

Street Food Market Pasar Kampoeng Kopat Boyolangu Village Giri District

Banyuwangi Regency

empowerment in this research will be how the community process can understand, and utilize opportunities that are owned, integrated and cooperate, make decisions and apply in the form of a product of activities carried out in order to solve problems and find solutions to opportunities and opportunities.

\subsubsection{Use of Symbols of Community Values and Traditions}

Utilization of Symbols of Community Values and Traditions is carried out through symbols that already exist in the community. The symbol can be in the form of traditional values in the community. Furthermore, the symbol is used as a medium in community empowerment activities. The symbol is used as a strategy for community empowerment. The traditional strategy suggests that people know and choose the best interests freely in various circumstances. In other words, all parties are free to determine their own interests and there is no other party that interferes with the freedom of each party. Traditional strategies depart from the basic potential that exists and is already owned by the community. So that when it goes to be developed further, the community feels that it is in line with the values and symbols that are owned by the community. Based on this, automatically, awareness will appear naturally without coercion in accordance with what is the basic value of society. Natural awareness of the community will foster community independence. Such independence will lead to innovation and creative ideas, especially in the socio-economic field so that they will be able to become more financially independent so that they can fulfill the basic needs of people's lives. These efforts will be able to increase the dignity and the standard of living of the people.

As for this research, we will study how to empower the community through the activities of Street Food Market, Kampoeng Kopat Market, Boyolangu Village, Giri District, Banyuwangi Regency. The stages of activities include: the preparation stage, the stage of assessment (assessment), the alternative planning stage of the program or activity, the stage of focusing on the action plan, the implementation stage (implementation) of the program or activity, the evaluation phase, the termination stage.

\subsection{Street Food Market Kampat Kopat Market, Boyolangu Village, Giri District, Banyuwangi Regency}

The Banyuwangi Pesona Indonesia (GenPI) Generation Community presents a new digital destination, Kampoeng Kopat. This digital destination was first released on October 19-20 2018, starting at 19:00 WIB. The location is in Boyolangu, Giri, Banyuwangi. Kampoeng Kopat stands for dari Kumpul Teko Punjer Papat '. The birth of this market is also unique. Starting from the anxiety of the Banyuwangi GenPI after the Banyuwangi Ethno Carnival (BEC) event. BEC took the theme of the Kayun Puter which became the local wealth and wisdom of the Boyolangu community where BEC raised the Kayun Puter. After the BEC activities were finished, there was practically no activity. Then the Kampoeng Kopat market plan was socialized to the community. The result was a very enthusiastic response from the community. This market was developed independently by the Boyolangu community. The hope of this destination can be the best economic driver for the community. The Kampoeng Kopat market is also directed as a 
Proceeding ICOGISS 2019

Page 81-90. ISBN: 978-602-6 988-75-1

Web Jurnal Online: jurnal.unmuhjember.ac.id

By: Putri Robiatul Adawiyah

Street Food Market Pasar Kampoeng Kopat Boyolangu Village Giri District

Banyuwangi Regency

millennial generation expression media in Boyolangu from the Boyolangu community that has high creativity and productivity. Kampoeng Kopat operates every Saturday night, the market is opened after sunset until 21.00 WIB. There are a variety of facilities prepared, Instagramable photo spots, as well as various other accessories and entertainment.

\section{RESEARCH METHODS}

\subsection{Stages of Research}

In this study the stages of research carried out are based on research boundaries, including the following: a. Identify what potentials the community has b. Identify what values and symbols are owned and utilized for community empowerment. c. Identification of process mechanisms and methods used by the community in integrating the concept of Street Food Market in Kampoeng Kopat. d. Analyzing data and data identification results. e. Formulation of data conclusions.

\subsection{Research Methods}

Types of research This type of research is quantitative descriptive research. According to Sugiyono (2009), the quantitative data obtained were processed descriptively and interpreted and analyzed. The activity of describing data is describing existing data in order to obtain a real form from the respondent, so that it is more easily understood by researchers or other people who are interested in the results of the research conducted. The activity of describing the data is done by descriptive statistical measurements. In this study, the data obtained will be processed quantitatively and then described according to the additional information obtained at the time of research, and when needed the researcher prepares questions with interviews which later can explain the contents or answers to questions or statements that are in the questionnaire or questionnaire has been answered by respondents, while still at the research location. The method of data collection was carried out using the direct communication interview method with respondents related to Kampoeng Kopat street food market activities in Boyolangu Banyuwangi Village.

\subsection{Research sites}

The research location taken by the researchers was the Kampoeng Kopat neighborhood of Boyolangu Village, Giri District, Banyuwangi Regency, where there were street food market activities in the village. 4.2.3. Research time The research time to carry out research is 3 months, namely mid-January-March 2019 which includes 1 . The process of initial observation, 2 . The process of determining respondents, 3 . The process of conducting research, 4. Process of data classification and reduction, 5. Data processing, 6. Process of data analysis, 7. Process of formulating research results and conclusions. 4.2.4. Population / Study Samples Determination of population research was purposive to respondents / informants, namely traditional leaders in Boyolangu Kampoeng Kopat, as well as some sellers and buyers related to street food market activities in Boyolangu Kampoeng Kopat, so that the total number of respondents taken in this study was 
Proceeding ICOGISS 2019

Page 81-90. ISBN: 978-602-6 988-75-1

Web Jurnal Online: jurnal.unmuhjember.ac.id

By: Putri Robiatul Adawiyah

Street Food Market Pasar Kampoeng Kopat Boyolangu Village Giri District

Banyuwangi Regency

approximately 20 people. 4.2.5. Sources and Data Collection Techniques The source and technique of data collection is to use it simply that is by using interviews assisted by interview guidelines. Data that has been obtained, then grouped, processed and analyzed to draw a conclusion. 4.2.6 Data Analysis Data analysis was performed using the Miles and Huberman models. Includes data reduction, data presentation, conclusion drawing, and data verification. The validity of the data uses the triangulation method.

\section{RESULTS}

\subsection{Community Potential of Boyolangu Village, Giri District, Banyuwangi Regency}

The community of Boyolangu Sub-District, Giri District, Banyuwangi Regency has a lot of potential. The potential is a legacy that has been inherited from generation to generation which has been preserved and preserved by the Boyolangu community. The potentials include the following:

1. Culinary Potential The Boyolangu community has culinary potential, among others, a variety of typical Boyolangu ketupat such as Ketupat Kare, Ketupat Opor, Ketupat Pecel Pitik, Ketupat Ndok Cit, Ketupat tempong sauce, traditional snacks, traditional drinks, etc. This potential is used by the Boyolangu community to support Kampong Kopat's Street Food Market activities in Boyolangu Village.

2. Potential of Customs Boyolangu community has various kinds of customs that are orchestrated by the people from generation to generation. The current transfer is carried out, among others, the Pute Kayun Tradition, Ider Bumi Barong, Syawalan Kupat Sewu, and Nyekar / Jakso Tombs' pilgrimage.

3. Tourism Potential Tourism potential in Boyolangu is not too prominent, but there is namely the existence of the great-grandson of Jakso. Jakso's great-grandfather is usually visited by tourists or tourists along with a visit to the "Buyut Cili" Chilean great-grandfather at Kemiren. In addition, tourism activities in Boyolangu are during the Kayun and Kupat Sewu Festival Festival held in Shawwal which is attended by many local and foreign tourists.

4. Potential "Kanggo Riko" Program Policy from the Government Banyuwangi Regency has a Smart Village Policy Program that applies throughout the Banyuwangi region. In the Smart Village Program there is an Activity Program, Kanggo Riko. Kanggo Riko is a women's empowerment program in the form of lending and venture capital assistance to women for micro-businesses. By the Boyolangu women's community, especially in the village of Kupat, the aid funds were used as business capital.

5. Potential for Women's Cooperatives Boyolangu Village has a cooperative whose management and members are women. The women's cooperative was used by the community of kupat village to apply for loans and provide venture capital assistance to make food for sale at Street Food Market. Not only in the form of food products, mothers can also sell souvenirs in the form of bags, wallets, handricrafts handmade handmade by the community of creative Paud mothers in Boyolangu. 
Proceeding ICOGISS 2019

Page 81-90. ISBN: 978-602-6 988-75-1

Web Jurnal Online: jurnal.unmuhjember.ac.id

By: Putri Robiatul Adawiyah

Street Food Market Pasar Kampoeng Kopat Boyolangu Village Giri District

Banyuwangi Regency

\subsection{Values and symbols that are owned and utilized for community empowerment in Boyolangu Village, Giri District, Banyuwangi Regency}

Boyolangu Village, Giri Subdistrict, Banyuwangi Regency has values and symbols that are used for Community Empowerment in Boyolangu Village, Giri District, Banyuwangi Regency. The values and symbols include the following:

1. Kayun Puter Symbol

Puter Kayun is a tradition carried out by the residents of Boyolangu, entering the tenth day of Shawwal. Puter kayun is a ritual to keep the promises of the citizens of Boyolangu to the ancestors who have contributed to paving the way in the northern region of Banyuwangi. They do a trail by riding an ornamental (delman) from Boyolangu to the coast of Watudodol. This tradition of ornamental delman ride was held in front of the Boyolangu village, Giri District. In the morning residents from various villages in Boyolangu gather in front of the village while riding ornamental buggies like a tourist carriage. While dressed in typical Using, which is wearing traditional clothes all black and white. Not forgetting to wear black glasses, they sat in a gig and were ready to do the puter kayun ritual towards Watudodol. The nature of the values contained in the Kayun Puter tradition are: religious values, values of responsibility, values of obedience and devotion, values of mutual cooperation, values of patriotism, values of affection, family values, tolerance, and values of gratitude and gratitude. The culture of the Kayun Puter tradition has been good enough as evidenced by the presence of the Culture and Tourism Office, Giri Sub-District Head and Boyolangu Village Head even the Banyuwangi District Head participated in the Kayun Puter tradition. And the enthusiasm of the Boyolangu community in following the Kayun Puter tradition.

2. Symbols of Torch and Barong Ider Bumi

Torch and Barong Ider Bumi is an event ritual carried out to reject balak which is usually carried out every 2nd of Shawwal. Ider Bumi means going around the Village in order to clear the Village of bad things and calamities. Barong is the figure of a tiger-headed animal with a dragon that is believed by the community as a symbol of virtue. When barong went around the village, flowers and yellow rice were scattered as well as loose change to be taken away by the community. If it is stored, it is believed that the community will bring blessings. During the Barong Ider Bumi activity, residents traveled around carrying torches around the village at night, and the lights were turned off by PLN for several hours.

3. Shawwal Kupat Sewu symbol

Ketupat is a symbol of Muslim society that is carried out every holiday. Ketupat is interpreted from the Arabic word which means disbelief, which is forgiveness. So that is interpreted by making ketupat to forgive each other. The tradition of making ketupat at the time of the Kupat sewu event was distributed during the Kayun Puter program. There are 1000 diamonds made and distributed to the Boyolangu community.

4. Jakso's great-looking symbol

Jakso's great-grandfather symbol is the origin of the emergence of the Puter Kayun tradition in relation to Watu Dodol, which is the breakdown of a large rock that blocks 
Proceeding ICOGISS 2019

Page 81-90. ISBN: 978-602-6 988-75-1

Web Jurnal Online: jurnal.unmuhjember.ac.id

By: Putri Robiatul Adawiyah

Street Food Market Pasar Kampoeng Kopat Boyolangu Village Giri District

Banyuwangi Regency

Banyuwangi's access to Surabaya. The solution was led by adopted son Nur Iman Ki Buyut Jakso with the demites. On orders from Ki Buyut Jakso. The purpose of carrying out the Kayun Puter tradition is to remember the services of Ki Buyut Jakso for opening the way for the cabbage coach and the Banyuwangi community, as a form of gratitude for the health, sustenance and security given by Allah SWT, and keeping the agreement made by Ki Buyut Jakso with Raja Demit, the procession of the Puter Kayun tradition, which first blends in the grave of Ki Buyut Jakso, which is continued by tahlilan and bersi desa, the two processions or parades around the village by displaying the artistic potential of Boyolangu Village, and the three traditions of Puter Kayun around the city using a dock to Watu dodol continued with selametan and sea water bath.

\subsection{Mechanism of processes and methods used by the community in integrating the concept of Street Food Market in Kampoeng Kopat Market, Boyolangu Village, Giri District, Banyuwangi Regency}

The mechanism of the process and methods used by the community in integrating the concept of Street Food Market in Kampoeng Kopat Market, Boyolangu Village, Giri Subdistrict, Banyuwangi Regency is carried out by the Banyuwangi Generation Indonesian Community (GenPI) along with the local Government namely Boyolangu Village and community leaders who have various potentials to present new digital destination, Kampoeng Kopat. Deliberation to innovate Kampong Kopat was conducted in mid-2018. After the Banyuwangi Ethno Carnival (BEC) event where Boyolangu presented the Kayun Puter Festival which became the local wealth and wisdom of the Boyolangu community After the BEC activities were finished there were practically no activities. Then after it was decided the results of the deliberations were socialized by the Kampoeng Kopat market plan to the community. The result was a very enthusiastic response from the community. This market was developed independently by the Boyolangu community by utilizing women's cooperatives that provide business capital assistance to be used as capital to sell diamonds and traditional snacks as well as handicraft souvenirs etc. Hopefully this destination can be the best economic driver for the community and the millennial generation of expression media of the Boyolangu community have high creativity and productivity and innovation. In addition, the existence of symbols and values that the community has had from the beginning, has been attached to the heart of the community, so that awareness to participate and support the Street Food Market program automatically exists and grows in the Boyolangu community and supports the integration process. the product of Kampong Kopat Street Food Market in Boyolangu, Giri District, Banyuwangi Regency. 
Proceeding ICOGISS 2019

Page 81-90. ISBN: 978-602-6 988-75-1

Web Jurnal Online: jurnal.unmuhjember.ac.id

By: Putri Robiatul Adawiyah

Street Food Market Pasar Kampoeng Kopat Boyolangu Village Giri District

Banyuwangi Regency

\section{CONCLUSION}

The community of Boyolangu Sub-District, Giri Subdistrict, Banyuwangi Regency has a lot of potential, namely culinary potential, potential customs, tourism potential, potential policy programs, potential female cooperatives. The various potentials utilized by the Boyolangu Village in Giri District, Banyuwangi District are integrated through the process of integrating together by the government and the community through values and symbols that are used to empower the Boyolangu community to produce Kampoeng Kopat Street Food Market innovation in Boyolangu Village, Giri District Banyuwangi. 
Proceeding ICOGISS 2019

Page 81-90. ISBN: 978-602-6 988-75-1

Web Jurnal Online: jurnal.unmuhjember.ac.id

By: Putri Robiatul Adawiyah

Street Food Market Pasar Kampoeng Kopat Boyolangu Village Giri District

Banyuwangi Regency

\section{REFERENCE}

Fahrudin, Adi. 2012. Pemberdayaan, Partisipasi dan Penguatan Kapasitas Masyarakat. Bandung: Humaniora.

Najiati, Sri, dkk. 2005. Pemberdayaan Masyarakat di Lahan Gambut. Bogor: Wetlands International.

Hikmat, Harry. 2006. Strategi Pemberdayaan Masyarakat. Bandung: Humaniora. https://www.kajianpustaka.com/2017/11/tujuan-prinsip-dan-tahapanpemberdayaan-masyarakat.html

Mardikanto, Totok. 2014. CSR (Corporate Social Responsibility)(Tanggungjawab Sosial Korporasi). Bandung: Alfabeta.

Soekanto, Soerjono. 1987. Sosial Suatu Pengantar. Jakarta: Rajawali press.

Sugiyono. 2009. Metode Penelitian Kuantitatif Kualitatif dan R\&D. Bandung: Alfabeta.

Suharto, Edi. 2005. Membangun masyarakat memberdayakan rakyat. Bandung: Refika Aditama.

https://www.kabarbanyuwangi.info/destinasi-digital-pasar-kampoeng-kopat-siap-

meluncur-di-banyuwangi.html

https://news.detik.com/berita-jawa-timur 